\title{
PENGARUH MOTIVASI TERHADAP DISIPLIN KERJA PEGAWAI PADA DINAS ENERGI SUMBER DAYA MINERAL PROPINSI LAMPUNG DI BANDAR LAMPUNG
}

\author{
Sodirin \\ Fakultas Ekonomi Universitas Sang Bumi Ruwa Jurai \\ sodirin@fe.saburai.ac.id
}

\begin{abstract}
Abstrak. Kementerian Energi dan Sumber Daya Mineral mempunyai tugas menyelenggarakan urusan pemerintahan di bidang energi dan sumber daya mineral untuk membantu Presiden dalam menyelenggarakan pemerintahan negara. Sumbang saran kepada lembaga pemerintahan Dinas Energi Sumber Daya Mineral Propinsi Lampung di Bandar Lampung berkenaan dengan kajian sumber daya manusia tentang Motivasi dan Disiplin. manfaat penelitian ini adalah sebagai sumbang saran kepada lembaga pemerintahan Dinas Energi Sumber Daya Mineral Propinsi Lampung di Bandar Lampung berkenaan dengan kajian sumber daya manusia tentang Motivasi dan Disiplin. Tujuan penelitian ini adalah ingin mengetahui pengaruh motivasi pegawai terhadap disiplin kerja pegawai. Berdasarkan hasil uji $t$ didapat nilai $t_{\text {hitung }}=5,167$. Dan bila dibandingkan dengan $t_{\text {tabel }}$ pada taraf signifikan 0,05 yaitu 1,67 , maka $t_{\text {hitung }}=5,167>t_{\text {tabel }} 1,67$ kesimpulannya bahwa hipotesa yang menyatakan terdapat pengaruh antara variabel Motivasi $(\mathrm{X})$ terhadap Disiplin Kerja $(\mathrm{Y})$ pada Dinas Energi Sumber Daya Mineral Propinsi Lampung di Bandar Lampung.
\end{abstract}

Kata kunci: Pemerintahan dan Sumber Daya.

\section{PENDAHULUAN}

Kementerian Energi dan Sumber Daya Mineral dibentuk berdasarkan Peraturan Presiden Republik Indonesia Nomor 24 Tahun 2010 tentang Kedudukan, Tugas dan Fungsi Kementerian Negara serta Susunan Organisasi Tugas dan Fungsi Eselon I Kementerian Negara. Tugas Kementerian Energi dan Sumber Daya Mineral (ESDM) ini adalah menyelenggarakan urusan pemerintahan di bidang energi dan sumber daya mineral untuk membantu Presiden dalam menyelenggarakan pemerintahan negara. Kemudian dalam melaksanakan tugasnya Kementerian Energi dan Sumber Daya Mineral menyelenggarakan fungsi:

- Perumusan dan penetapan kebijakan di bidang pembinaan, pengendalian, dan pengawasan minyak dan gas bumi, ketenagalistrikan, mineral dan batubara, energi baru, energi terbarukan, konservasi energi, dan geologi;

- Pelaksanaan kebijakan di bidang pembinaan, pengendalian, dan pengawasan minyak dan gas bumi, ketenagalistrikan, mineral dan batubara, energi baru, energi terbarukan, konservasi energi, dan geologi serta pengelolaan Penerimaan Negara Bukan Pajak sektor energi dan sumber daya mineral sesuai dengan peraturan perundangundangan;

- Pelaksanaan bimbingan teknis dan supervisi atas pelaksanaan kebijakan di bidang pembinaan, pengendalian, dan pengawasan minyak dan gas bumi, ketenagalistrikan, mineral dan batubara, energi baru, energi 
terbarukan, konservasi energi, dan geologi;

- Pelaksanaan penelitian dan pengembangan di bidang energi dan sumber daya mineral;

- Pelaksanaan pengembangan sumber daya manusia di bidang energi dan sumber daya mineral;

- Pelaksanaan dukungan yang bersifat substantif kepada seluruh unsur organisasi di lingkungan Kementerian Energi dan Sumber Daya Mineral;

- Pembinaan dan pemberian dukungan administrasi di lingkungan Kementerian Energi dan Sumber Daya Mineral;

- Pengelolaan barang milik/kekayaan negara yang menjadi tanggung jawab Kementerian Energi dan Sumber Daya Mineral; dan

- Pengawasan atas pelaksanaan tugas di lingkungan Kementerian Energi dan Sumber Daya Mineral. (Kementerian Energi dan Sumber Daya Mineral dibentuk berdasarkan Surat Peraturan Presiden Republik Indonesia Nomor 24 Tahun 2010).

Menurut Manulung (2012:129) mendefinisikan "Motivasi adalah pekerjaan yang dilakukan oleh seseorang manajer untuk memberikan inspirasi, semangat, dan dorongan kepada orang orang lain, dalam hal ini karyawan untuk mengambil tindakan-tindakan. Pemberian dorongan ini bertujuan untuk menggiatkan karyawan agar mereka bersemangat dan dapat mencapai hasil sebagaimana dikehendak".

Oleh sebab itu dapat dikatakan bahwa adanya adanya kehadiran yang efektif menandakan bahwa motivasi kerja dapat meningkatkan dan menentukan kedisiplinan dengan harapan kedisiplinan dalam bentuk Sikap kesediaan dan kerelaan mematuhi dan mentaati norma-norma peraturan yang berlaku di sekitarnya termasuk kedisiplinan untuk selalu hadir dalam bekerja. Sikap kejiwaan seseorang atau sekelompok orang yang senantiasa berkehendak untuk mengikuti/mematuhi segala aturan/keputusan yang telah ditetapkan" (Singodimedjo, 2012: 86).

Beranjak dari latar belakang sebagimana disebutkan di atas, maka penulis mencoba melakukan penelitian dengan suatu judul "Pengaruh Motivasi terhadap Disiplin Kerja Pegawai Pada Dinas Energi Sumber Daya Mineral Propinsi Lampung di Bandar Lampung"

\section{KAJIAN TEORI}

\section{Motivasi}

Menurut Manulung (2014:129) telah mendefinisikan pengertian motivasi, yakni "Motivasi adalah pekerjaan yang dilakukan oleh seseorang manajer memberikan inspirasi, semangat, dan dorongan kepada orang orang lain, dalam hal ini karyawan untuk mengambil tindakan-tindakan. Pemberian dorongan ini bertujuan untuk menggiatkan karyawan agar mereka bersemangat dan dapat mencapai hasil sebagaimana dikehendak"

Menurut Hasibuan (2014:146), tujuan motivasi antara lain adalah sebagai berikut :

a. Meningkatkan moral dan kepuasan kerja karyawan.

b. Meningkatkan produktivitas kerja karyawan.

c. Mempertahankan kestabilan karyawan perusahaan.

d. Meningkatkan kedisiplinan karyawan.

e. Mengefektifkan pengadaan karyawan.

f. Menciptakan suasana dan hubungan kerja yang baik.

g. Meningkatkan loyalitas, kreatifitas, dan partisipasi karyawan.

h. Meningkatkan tingkat kesejahteraan karyawan.

i. Mempertinggi rasa tanggung jawab karyawan terhadap tugasnya. 
j. Meningkatkan efisiensi penggunaan alat-alat dan bahan baku.

Banyak sekali yang memberi pendapat tentang motivasi, hal ini sebagaimana pendapat Moorhead dan Griffin (2013:270) dalam Hasibuan (2014:146), yang mengatakan bahwa saat ini, secara virtual semua orang praktisi dan sarjana punya definisi motivasi tersendiri. Biasanya kata-kata berikut ini dimasukkan dalam definisi: hasrat, keinginan, harapan, tujuan, sasaran, kebutuhan, dorongan, motivasi, dan insentif.

Kemudian secara teknis dan etimologi (asal usul kata), istilah motivasi berasal dari kata Latin Movere, yang berarti "bergerak". Arti ini merupakan bukti dari definisi atau pengertian yang komprehensif sebagaimana berikut ini: Motivasi adalah proses yang dimulai dengan defisiensi fisiologis atau psikologis yang menggerakkan perilaku atau dorongan yang ditujukan untuk tujuan atau insentif. Dengan demikian, kunci untuk memahami proses motivasi bergantung pada pengertian dan hubungan antara kebutuhan, dorongan, dan insentif.

\section{Jenis-jenis Motivasi}

Adapula jenis motivasi yang dikemukakan oleh Gibson dan Donnelly (2012:105) ada dua, yaitu:

1. Motivasi Positif

Manajer memotivasi bawahan dengan memberikan hadiah kepada mereka yang berprestasi baik. Dengan motivasi baik ini semangat kerja bawahan akan tinggi karena manusia pada umumnya senang menerima yang baik-baik saja.

2. Motivasi Negatif

Manajer memotivasi bawahannya dengan memberikan hukuman kepada mereka yang pekerjaannya kurang baik (prestasi rendah). Dalam memotivasi negative ini semangat kerja dalam jangka waktu pendek akan meningkat. Karena mereka takut dihukum, tetapi dalam jangka waktu panjang akan berakibat kurang baik.

Dalam prakteknya kedua jenis motivasi ini sering dilakukan oleh manager dan perusahaan. Penggunaannya harus tepat dan seimbang supaya dapat meningkatkan motivasi kerja karyawan.

\section{Disiplin}

\section{Pengertian Disiplin}

Secara etomologis disiplin berasal dari bahasa inggirs "diciple" yang berarti pengikut atau penganut pengajaran, latihan dan sebagainya. Terdapat beberapa pendapat mengenai disiplin kerja yang dikemukakan oleh para ahli. Disiplin kerja didefinisikan berdasarkan beberapa kategori, dianataranya berdasarkan karyawan atau pegawai dan berdasarkan manajemen. Berikut adalah pendapat para ahli mengenai disiplin kerja berdasarkan karyawan yaitu: Disiplin kerja dapat diartikan sebagai kesadaran dan kesediaan seseorang menaati semua peraturan perusahaan dan norma-norma sosial yang berlaku (Hasibuan, 2002:193).

Kemudian pengertian disiplin merupakan suatu keadaan tertentu dimana orangorang yang bergabung dalam organisasi tunduk pada peraturanperaturan yang ada dengan rasa senang hati. Sedangkan kerja adalah segala aktivitas manusia yang dilakukan untuk menggapai tujuan yang telah ditetapkannya (Sinunungan, 2005:145).

Kedisiplinan dapat diartikan sebagai suatu sikap, tingkah laku dan perbuatan yang sesuai dengan peraturan tertulis maupun biasa dari suatu perusahaan atau instansi. Dengan demikian setiap perusahaan menetapkan atau merumuskan suatu aturan yang diberlakukan untuk menjamin terlaksananya mekanisme kerja instansi tersebut, untuk menciptakan prosedur kerja yang teratur sehingga 
mencapai tujuan organisasi dengan baik (Nitisemito, 2001).

\section{Tujuan Disiplin}

Menurut Sastrohadiwiryo (2002:291), disiplin yang diterapkan memiliki tujuan sebagai berikut:

1. Agar para tenaga kerja menepati segala peraturan dan kebijakan ketenagakerjaan maupun peraturan dan kebijakan perusahaan yang berlaku, baik tertulis maupun tidak, serta melaksanakan perintah manajemen.

2. Dapat melaksanakan pekerjaan dengan sebaik-baiknya serta mampu memberikan service yang maksimal kepada pihak tertentu yang berkepentingan dengan perusahaan sesuai dengan bidang pekerjaan yang dibebankan kepadanya.

3. Dapat menggunakan dan memelihara sarana dan prasarana, barang dan jasa perusahaan sesuai dengan bidang pekerjaan yang diberikan kepadanya.

4. Dapat bertindak dan berperilaku sesuai dengan normanorma yang berlaku pada perusahaan.

\section{METODE PENELITIAN}

\section{Objek Penelitian}

Objek dari penelitian ini Dinas Energi Sumber Daya Mineral Propinsi Lampung beralamat di Jalan Beringin Raya II No. 12, Teluk Betung, (Pos.35111) dimana penelitian ini berlangsung dari bulan Mei hingga Juni 2019.

\section{Metode dan Teknik Pengumpulan Data}

Dalam penelitian ini jenis data yang diperlakukan adalah :

a. Data primer

Data primer ini nantinya merupakan data yang diperoleh langsung tanpa perantara orang atau lembaga lain sebagai pihak ketiga. Data primer ini diperoleh dengan wawancara melalui responden dengan menggunakan daftar pertanyaan.

b. Data Sekunder

Data ini merupakan data yang diperoleh melalui orang lain yang berhubungan dengan permasalahan yang dipecahkan. Data sekunder ini diperoleh melalui cara studi dokumenter yaitu mengumpulkan dan mempelajari brosur-brosur serta dokumen kompetensi.

\section{Sampel dan Populasi}

Pada penelitian ini seluruh Karyawan dijadikan responden. Berdasarkan data yang ada jumlah pegawai adalah 121 orang, kemudian menurut S.Arikunto apabila objek penelitian lebih dari 100 maka lebih baik diambil sebagian yang besar 15 hingga 20 persen untuk dijadikan sebagai sampel. Menurut data yang ada jumlah populasi dalam penelitian ini berjumlah kurang 121 sehingga penulis mengambil sampel sebagai responden yaitu 20 persen atau berjumlah 24 orang.

\section{Metode Analisis Data}

Analisis kualitatif dilakukan dengan analisis tabel tunggal atau secara parsial yang akan menggambarkan kriteria masingmasing variabel yaitu kreteria variabel Motivasi dan Disiplin

Analisis kuantitatif yang dilakukan berdasarkan data primer yang diperoleh dari penyebaran instrument (daftar pertanyaan) kepada sampel, dan untuk mengetahui pengaruh dari variabel bebas (independent variable) terhadap variabel terikat (dependent variable).

Untuk mengetahui Pengaruh Motivasi dan Disiplin, maka analisis yang digunakan menggunakan rumus Regresi Tunggal : 


$$
Y=a+b X
$$

Dimana :

$\begin{array}{ll}\mathrm{Y} & =\text { Variabel Disiplin } \\ \mathrm{A} & =\text { Variabel Tetap } \\ \mathrm{b} & =\text { Koefisien (Peubah) } \\ \mathrm{X} & =\text { Variabel Motivasi }\end{array}$

Sofian Efendi (2012:121)

Selanjutnya melakukan perumusan untuk mengetahui besarnya pengaruh $\mathrm{X}$ terhadap Y sebagai berikut :

$$
\begin{gathered}
b=\frac{N \Sigma\left(X_{i} Y_{i}\right)-\left(\Sigma X_{i}\right)\left(\Sigma Y_{i}\right)}{\sqrt{\left.\left[N \Sigma X_{i}^{2}\right]\left[\Sigma Y_{i}\right)^{2}\right]}} \\
\operatorname{serta} \\
a=\frac{\Sigma y-b i\left(\Sigma X_{i}\right)}{N}
\end{gathered}
$$

Selanjutnya, kontribusi variabel bebas terhadap variabel terikat baik secara parsial maupun bersama-sama dapat dilihat pada model persamaan berikut ini, (Riduan, 2009) digunakan rumus :

$$
r_{x_{1} y}^{2}=\frac{\left\{n\left(\Sigma X_{1} Y\right)-\left(\Sigma X_{1}\right)(\Sigma Y)\right\}^{2}}{\left\{n\left(\Sigma X_{1}^{2}\right)-\left(\Sigma X_{1}\right)^{2}\right\}\left\{n\left(\Sigma Y^{2}\right)-(\Sigma Y)^{2}\right\}}
$$

Perhitungan seluruh koefisien determinasi tersebut diatas akan menggunakan paket program Statitical Product and Service Solution (SPSS versi 21). Kriteria yang dipergunakan secara umum sebagai penentu skor terhadap sejumlah pertanyaan yang diajukan kepada responden adalah berjarak " 5 " yaitu : $(1,2,3,4,5)$ yang akan dipergunakan dalam penulisan ini dengan asumsi sebagai berikut

(a) Sangat Setuju (SS), nilai 5

(b) Setuju (S), nilai 4

(c) Kurang Setuju (Ks), nilai 3

(d) Tidak Setuju (TS), nilai 2

(e) Sangat Tidak Setuju (STS), nilai 1
Kemudian untuk menyatakan besar atau kecilnya sumbangan dari variabel $X$ terhadap $\mathrm{Y}$ ditentukan dengan rumusan koefisien determinasi sebagai berikut :

$$
K P=r^{2} \times 100 \%
$$

Dimana

$\mathrm{KP}=$ Nilai Koefisien Determinasi

$\mathrm{r}^{2}=\quad$ Nilai Koefisien Korelasi

Sebagai pengujian lanjutannya yakni Korelasi Pearson Product Moment tersebut di uji dengan uji Signifikan dengan rumus :

$$
\text { Thitung }=\frac{r \sqrt{n-k}}{\sqrt{1-\mathrm{r}^{2}}}
$$

\section{Dimana}

$\mathrm{t}_{\text {hitung }}=$ nilai $\mathrm{t}$

$\mathrm{r}=$ Nilai koefisien korelasi

$\mathrm{n}=$ jumlah responden

$\mathrm{k}=$ variabel bebas $(\mathrm{X})$

Langkah berikut adalah melakukan Uji Hipotesis, dimana makna Pengujian hipotesis merupakan suatu tahapan dalam proses penelitian dalam rangka menentukan jawaban apakah hipotesis ditolak atau diterima.

a. Hipotesis nol / nihil $\left(\mathrm{H}_{\mathrm{O}}\right)$

Hipotesis nol tidak memiliki perbedaan atau perbedaannya nol dengan hipotesis sebenarnya.

b. Hipotesis alternatif/ tandingan $\left(\mathrm{H}_{1} / \mathrm{H}_{\mathrm{a}}\right)$ Hipotesis alternatif adalah hipotesis yang di rumuskan sebagai lawan atau tandingan dari hipotesis nol.

Dalam menyusun hipotesis alternatif, timbul 3 keadaan berikut.

1) $\mathrm{H}_{1}$ menyatakan bahwa harga parameter lebih besar dari pada harga yang di hipotesiskan. Pengujian itu disebut pengujian satu sisi atau satu arah, yaitu pengujian sisi atau arah kanan.

2) $\mathrm{H}_{1}$ menyatakan bahwa harga parameter lebih kecil dari pada harga yang di hipotesiskan. Pengujian itu disebut pengujian satu sisi atau satu 
arah, yaitu pengujian sisi atau arah kiri.

3) $\mathrm{H}_{1}$ menyatakan bahwa harga parameter tidak sama dengan harga yang di hipotesiskan. Pengujian itu disebut pengujian dua sisi atau dua arah, yaitu pengujian sisi atau arah kanan dan kiri sekaligus.

\section{HASIL DAN PEMBAHASAN}

\section{Analisis Kualitatif}

Disiplin Kerja Karyawan Dinas Energi Sumber Daya Mineral Propinsi Lampung di Bandar Lampung

\begin{tabular}{|l|l|l|l|}
\hline $\begin{array}{l}\text { N } \\
\mathbf{o}\end{array}$ & Menjawab Pernyataan & $\begin{array}{l}\text { Disipli } \\
\text { n Kerja }\end{array}$ & $\begin{array}{l}\text { Persantas } \\
\text { e }\end{array}$ \\
\hline $\mathbf{1}$ & Sangat Setuju (SS) & 8 & 21,05 \\
\hline $\mathbf{2}$ & Setuju (S) & 13 & 71,05 \\
\hline $\mathbf{3}$ & Kurang Setuju (Ks) & 3 & 7,90 \\
\hline $\mathbf{4}$ & Tidak Setuju (TS) & - & - \\
\hline $\mathbf{5}$ & $\begin{array}{l}\text { Sangat Tidak Setuju } \\
\text { (STS) }\end{array}$ & - & - \\
\hline & Jumlah & $\mathbf{2 4}$ & $\mathbf{1 0 0}$ \\
\hline
\end{tabular}

Sumber : Data Hasil Pengolahan

Dari tabel atas dasar daftar pertanyaan yang diajukan kepada responden, maka yang menyatakan memiliki Disiplin Kerja atau menjawab pernyataan dengan sangat setuju (SS) dalam hal hasil para pekerja, proses organisasi, terbukti secara konkrit, menyempurnakan tanggung jawab, dapat diukur, dapat dibandingkan dengan standar yang sudah ditentukan, kecakapan, pengalaman, kesungguhan dan waktu dengan maksimal adalah 8 orang atau $21,05 \%$.

Sedangkan responden yang mampu menjalankan Disiplin Kerja dengan jawaban pernyataan setuju (S), antara lain dalam hal hasil para pekerja, proses organisasi, terbukti secara konkrit, menyempurnakan tanggung jawab, dapat diukur, dapat dibandingkan dengan standar yang sudah ditentukan, kecakapan, pengalaman, kesungguhan dan waktu dengan maksimal 13 orang atau $71,05 \%$.
Sedangkan responden yang mampu menjalankan Disiplin Kerja dengan jawaban pernyataan kurang setuju (KS), antara lain juga dalam halhasil para pekerja, proses organisasi, terbukti secara konkrit, menyempurnakan tanggung jawab, dapat diukur, dapat dibandingkan dengan standar yang sudah ditentukan, kecakapan, pengalaman, kesungguhan dan waktu dengan maksimal 3 orang atau 7,90\%

Uji Hipotesis perhitungan pengaruh antara variabel Motivasi kerja (X) terhadap Disiplin Kerja (Y) pada Dinas Energi Sumber Daya Mineral Propinsi Lampung di Bandar Lampung, menggunakan hasil perhitungan melalui program SPSS For Windows dan hasil statistik adalah sebagai berikut :

Uji Hipotesis Pengaruh Motivasi Kerja (X) terhadap Disiplin Kerja (Y)

Coefficients $^{\mathrm{a}}$

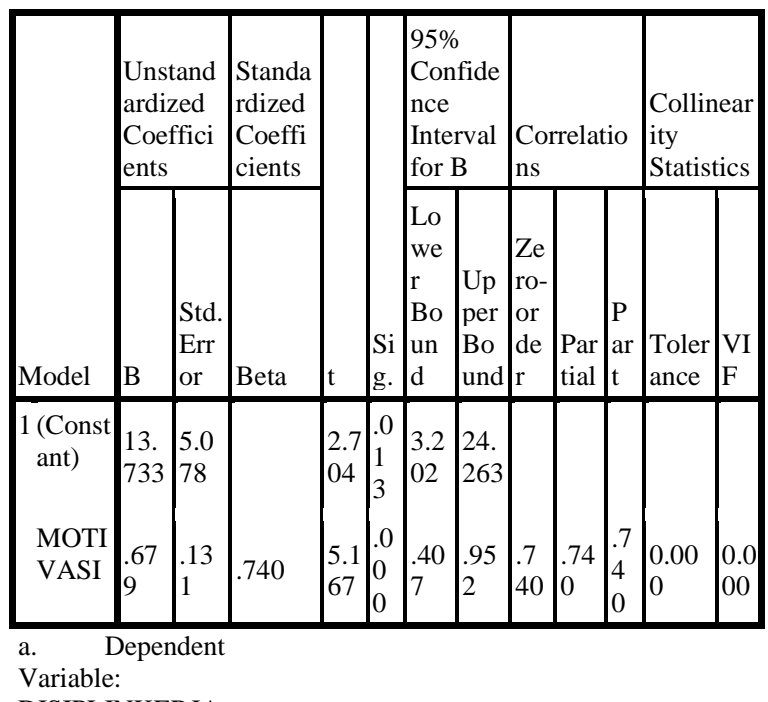

Berdasarkan hasil uji $\mathrm{t}$ didapat nilai $t_{\text {hitung }}=5,167$. Apabila dibandingkan dengan $t_{\text {tabel }}$ pada taraf signifikan 0,05 yaitu 1,67, maka $t_{\text {hitung }}=5,167>t_{\text {tabel }} 1,67$ sehingga dapat disimpulkan bahwa hipotesa yang menyatakan terdapat pengaruh antara variabel Motivasi kerja (X) terhadap Disiplin kerja (Y) pada Dinas Energi Sumber Daya Mineral Propinsi Lampung di Bandar Lampung. Jadi variabel Motivasi 
kerja $(\mathrm{X})$ berpengaruh terhadap variabel Disiplin kerja (Y).

Berdasarkan hasil penelitian yang menggunakan perhitungan statitistik korelasi rank kendall dapat dilihat pada table berikut :

Uji Correlations Motivasi kerja (X) dengan Disiplin Kerja (Y) Correlations

\begin{tabular}{|ll|l|l|}
\hline & & $\begin{array}{l}\text { MOTIVASI } \\
\text { KERJA }\end{array}$ & $\begin{array}{l}\text { DISIPLIN } \\
\text { KERJA }\end{array}$ \\
\hline $\begin{array}{l}\text { Pearson } \\
\text { Correlation }\end{array}$ & $\begin{array}{l}\text { DISIPLINKERJA } \\
\text { MOTIVASI }\end{array}$ & 1.000 & .740 \\
\hline Sig. (1-tailed) & DISIPLINKERJA &. & 1.000 \\
& MOTIVASI & .000 & .000 \\
\hline $\mathrm{N}$ & DISIPLINKERJA & 24 & 24 \\
& MOTIVASI & 24 & 24 \\
\hline
\end{tabular}

**. Correlation is significant at the 0.01 level (2-tailed). Data diolah Tahun 2019)

Berdasarkan Tabel di atas diperoleh bahwa koefisien korelasi Motivasi (X) dengan Disiplin Kerja (Y) sebesar 0,740 dengan nilai signifikansi sebesar 0,000. Hal ini dapat disimpulkan bahwa nilai signifikansi sebesar 0,000 lebih kecil dari 0,05 yang berarti bahwa kedua variabel tersebut terdapat hubungan yang signifikan, hipotesis alternative (Ha) diterima dan hipotesis nol (Ho) ditolak. Dengan demikian, secara statistik hipotesis yang menyatakan terdapat hubungan positif Motivasi (X) dengan Disiplin Kerja (Y) pegawai terbukti dan dapat diterima. Hasil perhitungan koefisien korelasi tersebut selanjutnya untuk mengetahui signifikansi variabel Motivasi kerja (X) dengan Disiplin Kerja (Y) dihitung dengan rumusan $t_{\text {hitung }}$

thitung $=\frac{r \sqrt{n-1}}{\sqrt{1-\mathrm{r}^{2}}}=$ thitung $=\frac{0,740 \sqrt{24-1}}{\sqrt{1-0,740^{2}}}$,

maka didapat nilai $\underline{\mathbf{5 , 5 8 0 1}}$ sehingga dari hitungan tersebut dengan ketentuan @ $=0,05, \mathrm{dk}=\mathrm{n}-1=(24-1)=23$ didapat $\mathrm{t}$ tabel 1,67 yang ternyata $\mathrm{t}$ hitung $>\mathrm{t}$ tabel, maka antara variabel Motivasi

(X) dengan
Disiplin Kerja (Y) terdapat pengaruh yang signifikan.

Adapun besarnya nilai koefisien determinasi (KD) Motivasi (X) dengan Disiplin Kerja (Y) dapat dihitung sebagai berikut :

$$
\begin{gathered}
K P=r^{2} \times 100 \% \\
=5,58012 \times 100 \% \\
=31,14 \%
\end{gathered}
$$

Berdasarkan perhitungan tersebut dapat diartikan bahwa nilai koefisien determinasi Motivasi (X) dengan Disiplin Kerja (Y) pegawai adalah sebesar 31,14\%. Hal ini mengandung arti bahwa besarnya hubungan antara Motivasi (X) dengan Disiplin Kerja (Y) adalah sebesar 31,14\%. Sedangkan sisanya yaitu sebesar $68,86 \%$ merupakan hubungan variabel lain selain disiplin misalnya kepemimpinan, lingkungan kerja dan lain sebagainya sehingga tidak hanya disiplin saja yang mendeterminasikan Disiplin Kerja karyawan atau pegawai.

\section{KESIMPULAN DAN SARAN}

\section{Kesimpulan}

Berdasarkan hasil uji $\mathrm{t}$ didapat nilai $t_{\text {hitung }}=5,167$. Dan bila dibandingkan dengan $t_{\text {tabel }}$ pada taraf signifikan 0,05 yaitu 1,67, maka $t_{\text {hitung }}=5,167>t_{\text {tabel }} 1,67$ kesimpulannya bahwa hipotesa yang menyatakan terdapat pengaruh antara variabel Motivasi (X) terhadap Disiplin Kerja (Y) pada Dinas Energi Sumber Daya Mineral Propinsi Lampung di Bandar Lampung. Jadi variabel Motivasi (X) berpengaruh terhadap variabel Disiplin Kerja (Y) dapat diterima. Kemudian berdasarkan Koefisien Determinasi (KD) $\mathrm{R}^{2}=0,740^{2}=0,548=0,548 \times 100=54,8 \%$. Dapat disimpulkan bahwa variabel Disiplin kerja menjelaskan variasi perubahan terhadap variabel Disiplin Kerja pada Dinas Energi Sumber Daya Mineral Propinsi 
Lampung di Bandar Lampung sebesar $54,8 \%$, sedangkan sisanya dijelaskan oleh faktor lain yang tidak dikaji dala penelitian ini. Sedangkan persamaan regresi antara variabel motivasi terhadap Disiplin Kerja adalah $=5,784+0,679 \mathrm{X}$, yang artinya setiap kenaikan satu point daripada variabel Motivasi akan diikuti oleh naiknya variabel Disiplin Kerja pada Dinas Energi Sumber Daya Mineral Propinsi Lampung di Bandar Lampung sebesar 0,679 point.

\section{Saran}

Sebagai saran dari hasil penelitian ini sebagai bentuk rekomendasi, adalah sebagai berikut :

1. Bagi para pegawai pada Dinas Energi Sumber Daya Mineral Propinsi Lampung di Bandar Lampung, sebaiknya berusaha selalu menjaga dan meningkatkan Motivasi dalam bekerja terutama pada aspek penelaahan yang berkaitan dengan peningkatan moral dan kepuasan kerja karyawan.

2. Bagi Peneliti Berikutnya oleh karena Pengaruh Motivasi terhadap Disiplin Kerja Pegawai Dinas Energi Sumber Daya Mineral Propinsi Lampung di Bandar Lampung berdasarkan Nilai $\mathrm{R}^{2}$ yang diperoleh adalah sebesar 0,548 atau $54,8 \%$ yang menunjukkan variabel Motivasi dalam menjelaskan variasi yang terjadi pada Disiplin Kerja karyawan 54,8\%, sedangkan sisanya sebesar $45,2 \%$ dijelaskan oleh variabel lain yang tidak dimasukkan ke dalam model.

\section{DAFTAR PUSTAKA}

Harsuko, 2016. Mendongkrak Motivasi dan Kinerja : Pendekatan Pemberdayaan SDM,. Malang: UB Press.

Ismiyanto, PC. S., M. Pd. 2015. Metode Penelitian. Semarang : FBS UNNES.
Kotler, Philip dan Amstrong. 2016. PrinsipPrinsip Manajemen. Edisi KeSebelas. Alih Bahasa Oleh Damos Sihombing, MBA. Jakarta:Penerbit Erlangga

Mangkunegara, Anwar Prabu. 2015. Evaluasi Kinerja Sumber Daya Manusia. Bandung: Refika Aditama.

Mulyadi. 2015 Manajemen Sumber Daya Manusia. Jakarta :Penerbit In Media.

Nazir, Moh. 2015. Metode Penelitian. Bogor: Ghalia Indonesia.

Noor, Juliansyah. 2014. Metodologi Penelitian. Jakarta: Kencana Prenada Media Group

Pasolong, Harbani. $2017 . \quad$ Teori Administrasi Publik. Edisi Revisi. Bandung: Alfabeta .

Siagian, Sondang P. 2018. Manajemen Sumber Daya Manusia . Cetakan: 18. Jakarta : Penerbit Bumi Aksara.

Simamora, Henry. 2017. Manajemen Sumber Daya Manusia. Jakarta: STIE YKPN .

Singarimbun, Masri. 2017. Metode Penelitian Survey. LP3S - Jakarta.

Stephen, P.Robbins. 2018. Perilaku Organisasi. Alih Bahasa : Benyamin Molan. Edisi Ke Dua Belas. Jakarta. Penerbit : PT.Indeks, Kelompok Gramedia

Sutrisno, Hadi. 2014. Manajemen Sumber Daya Manusia. Edisi Kedua. Jakarta : Kencana Prenada Media Group.

Sugiyono. 2017. Metode Penelitian Administrasi. Bandung : Penerbit Alfabeta. 